\title{
Perceived Effect of Climate Variation on Poultry Production in Oke Ogun Area of Oyo State
}

\author{
O. A. Alade ${ }^{1} \&$ A. O. Ademola ${ }^{2}$ \\ ${ }^{1}$ Department of Agricultural Technology, The Polytechnic Ibadan, Oyo State, Nigeria \\ ${ }^{2}$ Department of Agricultural Extension and Rural Development, University of Ibadan, Ibadan, Nigeria \\ Correspondence: O. A. Alade, Department of Agricultural Technology, the Polytechnic Ibadan, Oyo State, \\ Nigeria. Tel: 234-080-3807-9312. E-mail: aladeoluwaseun@yahoo.com
}

\author{
Received: May 9, 2013 Accepted: July 15, 2013 Online Published: August 15, 2013 \\ doi:10.5539/jas.v5n9p176 URL: http://dx.doi.org/10.5539/jas.v5n9p176
}

\begin{abstract}
Climate variation is posing a threat to livestock production, especially the poultry enterprise. This study examined perceived effects of climate variation on poultry production in Oke Ogun area of Oyo State. One hundred and eighty poultry farmers were sampled for this study. Data were collected with interview schedule, described with frequencies and percentages, and analysed with chi-square. Result shows that $81.7 \%$ of the poultry farmers were male, $73.3 \%$ were married, and $8.3 \%$ had tertiary education. Most of the poultry farmers were aware of high temperature, change in rainfall pattern and intensity, loss of biodiversity and environmental degradation. Radio, friends, and family were their main sources of information on climate variation. Some of the effects of climate variation on poultry production were increase in feed intake of birds, outbreak of pests and diseases, and decrease in poultry products. Changes in feed formulation, use of well ventilated housing system and provision of more water ad-libitum were some of the measures taken to control these effects. It is concluded that the more the education and income of poultry farmers, the higher the measures used in controlling the effects of climate variation. Poultry farmers should be well informed on the best practices to reduce the adverse effect of climate variation on poultry enterprise to ensure continual production in changing times.
\end{abstract}

Keywords: climate variation, poultry enterprise, livestock production, coping strategies

\section{Introduction}

Climate variation is a persistent change in the mean of climate parameters (temperature, rainfall, humidity and soil moisture) due to change in the composition of atmospheric gases. Krishna (2011) stated that the change in the atmospheric composition is attributed to the emissions of green house gases (GHG) such as Carbon dioxide $\left(\mathrm{CO}_{2}\right)$, Methane $\left(\mathrm{NH}_{4}\right)$, Nitrogen oxide $\left(\mathrm{N}_{2} \mathrm{O}\right)$ and other gases. Climate variation is a shift in the average weather that a given area experiences. It occurs over a period of time which may range from several decades to centuries. It has been observed across the globe that there has always been a change in the climate of an area for a period of 30-100 yrs manifesting in earthquakes, flooding, tsunami, tornadoes, fluctuations in rainfall and temperature.

Intergovernmental Panel on Climate Change (2007) made it certain that climate variation is taking place. Climate variation is a global issue because it does not only affect the poor and developing countries but is also facing the developed world with flooding, earthquakes, cyclones, tornadoes and wild fires. It is clear that climate variation in many parts of the world adversely affects socioeconomic sectors which include water resources, agriculture, forestry, fisheries and animal husbandry. It is a phenomenon that will continue to occur; mitigating its effects is the only way out. The intricacy of climate variation is now receiving so much attention due to its impacts on both living and non-living creatures (Osaguona, 2009). Farmers are facing a lot of challenges due to climate variation and it may not be clear in empirical terms what loss farmers incur but it is known to cause more harm to their production than good.

There are many human factors that are responsible for climate variation across the globe like poor environmental sanitation, deforestation, bush burning, drilling of boreholes, fuel combustion, and cement manufacture. Agriculture is responsible for 14 percent of global Green House Gases (GHG) emissions and livestock plays a considerable role in climate variation in terms of their contribution to GHG emissions (Steinfeld et al., 2006; Krishna, 2011). The greatest effect of climate variation has however been predicted to be in the animal production 
in Sub- Saharan Africa (Adesoji \& Famuyiwa, 2010). Livestock accounts for 40 percent of agricultural Gross Domestic Product (GDP) and employs 1.3 billion people while supporting the livelihoods of one billion of the world's poor (Food and Agriculture Organization, 2007).

Poultry production is a major source of protein which has empowered poultry farmers to secure a means of survival and livelihood. Climate variation affects poultry production by reducing poultry yield and nutritional quality of feeds, increasing disease and disease-spreading pests, reducing water availability and making it difficult for birds to survive (Spore, 2008). Climate variation manifests as rise in temperature causing a fall in humidity and provides a medium for fungal and bacterial growth. Disease outbreak becomes inevitable; diseases like coccidiosis, haemorrhagic syndrome, fowl pox, and bronchitis will thus be on the increase. Rowlinson (2008) stated that change in temperature will reduce the rate of poultry feed intake causing poorer performance. Given that the effects of climate variation can only be mitigated, it is pertinent to determine aforehand the perceived effect of the trend by the people most involved. Therefore, this study aims to determine poultry farmers' perception of the effects of climate variation on poultry production. The study was conducted in Oke Ogun Area of Oyo State because of the density of poultry farmers in the area. The specific objectives of the study are to:

1) Determine the socioeconomic characteristics of the poultry farmers;

2) Ascertain their awareness of climate variation;

3) Identify their sources of information on climate variation;

4) Describe farmers' perceived effects of climate variation on poultry production; and

5) Isolate measures employed in mitigating effects of climate variation on poultry production.

\section{Methodology}

The study was carried out in Oke Ogun Area of Oyo State, Nigeria. Oke Ogun is in the Northern part of Oyo State and comprises ten local government out of the thirty-three Local Governments Areas (LGAs) in the state which are Atisbo, Orelope, Itesiwaju, Iwajowa, Irepo, kajola, Olorunsogo, Iseyin, Saki West and Saki West. It has a land area of 15,190,322 square kilometer and share boundaries with Kwara State in the North east, Ibarapa to the south east, Benin Republic to the West and Ogbomoso and Atiba to the East. Oke-Ogun has an estimated population of $1,579,940$ and dominated by the Yorubas, Hausas, Tivs, Egede, Fulani and Pinrapinra. The area is endowed with expanse of land suitable for cultivation of yam, cassava, millet, cowpea, shear, locust bean and rearing of animals like poultry, cattle, sheep and goat.

Multistage random sampling was used to select respondents for the study. Simple random sampling was used to select three LGAs; namely Saki East, Iwajowa and Atisbo LGAs. Ten percent of the villages in the three LGAs were randomly selected to give four (4) in Saki East, three (3) in Iwajowa and three (3) in Atisbo LGA; giving a total of 10 villages. Eighteen poultry farmers (with range of between 50 and 200 birds) were selected through purposive and snowballing sampling techniques in each village to give a total of one hundred and eighty (180) poultry farmers that form the sample size for the study. Data was collected using structured interview schedule; frequencies, percentages and chi square were used to describe and analyze the data. 


\section{Results and Discussion}

The socioeconomic distribution of the poultry farmers are presented in Table 1 below.

Table 1. Socioeconomic distribution of respondents

\begin{tabular}{lll}
\hline Variables & Frequency & Percentage \\
\hline Sex & & \\
Male & 147 & 81.7 \\
Female & 33 & 18.3 \\
Age & & \\
$<\mathbf{3 0}$ & 48 & 26.7 \\
$\mathbf{3 0 - 3 9}$ & 68 & 37.8 \\
$\mathbf{4 0 - 4 9}$ & 46 & 25.5 \\
$\mathbf{5 0 - 5 9}$ & 18 & 10.0
\end{tabular}

Marital status

\begin{tabular}{lll} 
Single & 48 & 26.7 \\
Married & 132 & 73.3 \\
Level of education & & \\
No formal education & 39 & 21.7 \\
Primary & 90 & 50.0 \\
Secondary & 36 & 20.0 \\
Tertiary & 15 & 8.3 \\
Primary occupation & & \\
Poultry keeping & 118 & 65.6 \\
Trading & 40 & 22.2 \\
Artisan & 22 & 12.2 \\
Annual income & & \\
$<\mathbf{5 0 , 0 0 0}$ & 65 & 36.1 \\
50,001-100,000 & 63 & 35.0 \\
100,001-150,000 & 32 & 17.8 \\
$>$ >150,000 & 20 & 11.1 \\
Source of capital & & \\
Self & 143 & 79.4 \\
Bank loan & 5 & 2.8 \\
Poultry association & 20 & 11.1 \\
Family and friends & 12 & 6.7 \\
\hline
\end{tabular}

Source: Field survey, 2011.

Table 1 indicates that majority (81.7\%) of the respondents were male, corroborating Amos (2006) and showing the uneven gender distribution in poultry production in the study area. It also shows that $73.3 \%$ of the respondents were married showing the significance of the enterprise in meeting family needs and welfare. Only $8.3 \%$ of the poultry farmers had tertiary education implying that most of the respondents were not educated enough to avail themselves with information on climate variation and its adaptive strategies. However, $65.6 \%$ of the farmers had poultry farming as their primary occupation implying that the enterprise is viable in the area. Result of analysis also showed that the enterprise is mostly self financed (79.4\%) which implied low capitalization and the consequent low income as $71.1 \%$ of the poultry farmers make less than $=\mathrm{N}=100,000$ annually from poultry keeping. 
Table 2. Distribution on awareness of climate variation

\begin{tabular}{lllll}
\hline Variables & $\begin{array}{l}\text { Yes } \\
\text { Frequency }\end{array}$ & Percentage & $\begin{array}{l}\text { No } \\
\text { Frequency }\end{array}$ & Percentage \\
\hline High temperature & 160 & 88.9 & 20 & 11.1 \\
Unfamiliar disease symptoms & 154 & 85.6 & 26 & 14.4 \\
Varying rainfall pattern & 172 & 95.6 & 8 & 4.4 \\
High rainfall intensity & 125 & 69.4 & 55 & 30.6 \\
Drier air & 106 & 58.9 & 74 & 41.1 \\
Prolonged dry season & 94 & 52.2 & 86 & 47.8 \\
\hline
\end{tabular}

Source: Field survey, 2011.

Table 2 shows that variation in climate is obvious and needs no second guessing. Poultry keepers were well aware of higher temperature $(88.9 \%)$, higher rainfall intensity $(69.4 \%)$, unfamiliar poultry disease symptoms $(85.6 \%)$, and unpredictable rainfall $(95.6 \%)$. Result of analysis is in concordance with Elijah and Adedapo (2006) and implies that variations in climate are simple and evident; they revolve around heat and rainfall intensities and deviations.

Table 3. Distribution of information sources

\begin{tabular}{lllll}
\hline Variables & $\begin{array}{l}\text { Yes } \\
\text { Frequency }\end{array}$ & Percentage & $\begin{array}{l}\text { No } \\
\text { Frequency }\end{array}$ & Percentage \\
\hline Radio & 159 & 88.3 & 21 & 11.7 \\
Television & 72 & 40.0 & 108 & 60.0 \\
Extension agent & 20 & 11.1 & 160 & 88.9 \\
Friends and family & 160 & 88.9 & 20 & 11.1 \\
Print & 67 & 37.2 & 113 & 62.8 \\
Internet & 10 & 5.6 & 170 & 94.4 \\
Other poultry farmers & 154 & 85.6 & 26 & 14.4 \\
\hline Sour
\end{tabular}

Source: Field survey, 2011.

As shown in table 3 below, poultry keepers are not well informed about how well to mitigate the effects of climate variation. Majority of them get most of their information from radio, and family and friends. This supports the findings of Yahaya (2002) that radio is a potent source of information to farmers and their families. However, radio air agricultural programs that are more crops inclined, than livestock specific. Also, family and friends are not to be trusted with professional information, even information from other poultry farmers could be more of trial and error sourced.

Table 4. Percentage distribution of poultry farmers' perception of the effects of climate variation on poultry production

\begin{tabular}{llllll}
\hline Variables & SA & A & U & D & SD \\
\hline Increased feed intake & 29.4 & 50.0 & 5.0 & 5.6 & 10.0 \\
High feeding cost & 72.2 & 15.6 & 2.8 & 6.7 & 2.8 \\
Feed wastage & 14.4 & 25.0 & 5.6 & 27.8 & 27.2 \\
High maintenance cost & 22.2 & 34.4 & 11.7 & 27.2 & 4.4 \\
Higher disease outbreak & 25.6 & 44.4 & 7.8 & 13.9 & 8.3 \\
Unhealthy/smaller poultry products & 22.2 & 51.1 & 6.7 & 3.3 & 16.7 \\
Lower response to treatment & 19.4 & 22.2 & 19.4 & 26.1 & 12.8 \\
\hline
\end{tabular}

Source: Field survey, 2011. 
From all indications, Table 4 implies that climate variation increases the production cost of poultry keepers. The value of poultry products were reduced as a result of incessant ill health and profit is consequently reduced. This is in support of Spore (2008) which asserts that climate variation will cause increase in diseases and disease pests. Research survey reports the production of thin egg shells, small egg sizes and bird life weight, agreeing with (Demeke, 2004). This threatens protein production and utilization as well as the achievement of food security in the area.

Table 5. Distribution of respondents according to measures for controlling effects of climate variation on poultry production

\begin{tabular}{lllll}
\hline Variables & $\begin{array}{l}\text { Yes } \\
\text { Frequency }\end{array}$ & Percentage & $\begin{array}{l}\text { No } \\
\text { Frequency }\end{array}$ & Percentage \\
\hline Change in feed formulation & 135 & 75.0 & 45 & 25.0 \\
Well ventilated housing & 156 & 86.7 & 24 & 13.3 \\
Tree planting around pens & 105 & 58.3 & 75 & 41.7 \\
Chemotherapy & 32 & 17.8 & 148 & 82.2 \\
More space per bird & 150 & 83.3 & 30 & 16.7 \\
More water served & 170 & 94.4 & 10 & 5.6 \\
Better hygiene & 162 & 90.0 & 18 & 10.0 \\
Less heat supply & 102 & 65.0 & 63 & 35.0 \\
\hline
\end{tabular}

Source: Field survey, 2011.

Table 5 shows that poultry keepers change feed formulation, use well ventilated housing system, increase space per bird, provide water ad libitum and ensure better hygiene. These are common measures in climate change mitigation among poultry farmers as also concluded by Olanrewaju et al. (2010). Respondents were of the opinion that the use of concrete made roofing slabs will prevent heat, though costly, they expected it to last longer. Giving more spacing per average bird will prevent generation of heat from birds and well ventilated housing will stabilize the relative humidity which will reduce the outbreak of pests and diseases.

Table 6. Relationship between socioeconomic characteristics of respondents and their awareness on climate variation

\begin{tabular}{lllll}
\hline Variables & Chi-square value & df & Significance & Decision \\
\hline Sex & 24.067 & 1 & $\mathrm{p}>0.05$ & $\mathrm{NS}$ \\
Age & 28.167 & 3 & $\mathrm{p}>0.05$ & $\mathrm{NS}$ \\
Level of education & 76.833 & 3 & $\mathrm{p}<0.05$ & $\mathrm{~S}$ \\
Level of income & 84.585 & 3 & $\mathrm{p}<0.05$ & $\mathrm{~S}$ \\
\hline
\end{tabular}

$\mathrm{df}=$ degree of freedom; $\mathrm{S}=$ Significant; $\mathrm{NS}=$ Not Significant, Significant at $\mathrm{p}<0.05$.

Source: Field survey, 2011.

Table 6 shows the relationship between measures used in controlling effects of climate variation and some socioeconomic characteristics of the respondents. Level of education and level of income were significantly related to measures in controlling effects of climate variation, which is in agreement with Adesiji et al. (2013). This implies that the more educated an individual is, the more he/she will be exposed to various ways of controlling the effects of climate variation and the more he/she will be able to search for information from the media and extension. Also, the level of income of an individual will determine how much information cost the individual can bear. Poultry farmers with high income were more disposed to production information because they needed to protect their investment. However, climate change awareness did not differ across age groups and gender. 


\section{Conclusion and Recommendations}

The study concluded that majority of poultry farmers in Oke-Ogun area of Oyo State were male, married and educated. Most of them were aware of high temperature, varying rainfall pattern, high rainfall intensity and unfamiliar disease symptoms. Some of the effects of climate variation on poultry production are increase in feed intake, higher disease outbreak, unhealthy/smaller/fewer poultry products and general increase in production cost. These adverse effects of climate variation were been mitigated in poultry production through change in feed formulation to reduce cost, serving more water to reduce heat, use of more ventilated and spacious housing system and increasing the hygienic practices.

It is therefore recommended that poultry farmers should be well informed on the best practices to reduce the adverse effect of climate variation on poultry enterprise through research and extension, using appropriate communication channels (radio) to ensure optimum production. Efforts should be made to reduce human activities that contribute to the occurrence of climate variation. Private organizations and NGOs should also be encouraged to sponsor radio jingles that create climate variation awareness, knowledge, and mitigating measures.

\section{References}

Adesiji, G. B., Baba, S. T., \& Tyabo, I. S. (2013). Effects of climate change on poultry production in Ondo State, Nigeria. Russian Journal of Agricultural and Socio-Economic Sciences, 2(14), 55-60.

Adesoji, S. A., \& Famuyiwa, B. S. (2010). Perception and Adaptation to Climate Change among Fulani Cattle Rearers in Osun State, Nigeria. Proceedings of $15^{\text {th }}$ Annual National Conference, AESON 10-14 $4^{\text {th }}$ May, 2010.

Amos, T. T. (2006). Analysis of Backyard Poultry Production in Ondo State, Nigeria. International Journal of Poultry Science, 5(3), 247-250. http://dx.doi.org/10.3923/ijps.2006.247.250

Demeke, S. (2004). Egg Production and Performance of local white leghorn hens under intensive and rural household conditions in Ethiopia. LRRD 16: 2.

Elijah, O. A., \& Adedapo, A. (2006). The effect of climate on poultry productivity in Ilorin Kwara State, Nigeria. International Journal of Poultry Science, 5(11), 1061-1068. http://dx.doi.org/10.3923/ijps.2006.1061.1068

Food and Agriculture Organization. (2007). Adaptation to Climate Change in Agriculture, Forestry and Fisheries: Perspectives, Framework and Priorities. Rome: FAO.

Intergovernmental Panel on Climate Change. (2001). Climate Change: Synthesis Report. In R. T. Watson \& the Core Writing Team (Eds.), A Contribution of Working Group I, II and III to the Third Assessment Report of the Intergovernmental Panel on Climate Change. Cambridge, United Kingdom and New York, USA. Retrieved from http://www.ipcc.ch/pub/syren.g.htm

Intergovernmental Panel on Climate Change. (2007). Climate Change: Impacts, Adaptation and Vulnerability. Contribution of Working Group II to the Fourth Assessment Report of the Intergovernmental Panel on Climate Change: Cambridge (UK): Cambridge University Press.

Krishna, P. P. (2011). Economics of Climate variation for Smallholder Farmers in Nepal: A review. Journal of Agriculture and Environment, 12, 6-13.

Olanrewaju, H. A., Purswell. J. L., Collier, S. D., \& Branton, S. L. (2010). Effect of Ambient Temperature and Light Intensity on Growth Performance and Carcass Characteristics of Heavy Broiler Chickens at 56 Days of Age. International Journal of Poultry Science, 9(8), 720-725. http://dx.doi.org/10.3923/ijps.2010.720.725

Osaguona, P. O., Fajobi, E. A., Meduna A. J., Irokanulo, U. O., Ayeni, S. M., \& Ogunjobi, J. A. (2007). Effect of Climate Variation on the Environment. Proceedings of the Association of Women in Forestry and Environment (pp. 167-170).

Rowlinson, P. (2008). Adapting Livestock Production Systems to Climate Variation-Temperate Zones. Livestock and Global Change Conference Proceeding, May 2008, Tunisia.

Spore Magazine. (2008). Climate Variation: Pests and Diseases (pp. 5-6). Spore Magazine, August Special Issue: CTA.

Steinfeld, H., Gerber, P., Wassenaar, T., Castel, V., Rosales, M., \& de Hann, C. (2006). Livestock's Long Shadow: Environmental Issues and Options. Rome: FAO.

Yahaya, M. K. (2002). Gender and Communication Variables in Agricultural Information Dissemination in Two-Agro Ecological Zones of Nigeria. A Research Monograph. 


\section{Copyrights}

Copyright for this article is retained by the author(s), with first publication rights granted to the journal.

This is an open-access article distributed under the terms and conditions of the Creative Commons Attribution license (http://creativecommons.org/licenses/by/3.0/). 